and classification of birds. Yale Univ. Press, New Haven, CT.

Sibley, C. G., AND B. L. MonkoE. 1990. Distribution and taxonomy of birds of the world. Yale Univ. Press, New Haven, CT.

Sick, H. 1967. Rios e enchentes na Amazônia como obstáculo para a avifauna, p. 495-520. In H. Lent [ed.], Atas do simpósio sôbre a biota Amazônica. Vol. 5 (Zoologia). Conselho Nacional de Pesquisas, Rio de Janeiro.

SORENSEN, M. D. 1996. TreeRot. Computer program distributed by the author. Univ. Michigan, Ann Arbor, MI.

SORENSEN, M. D., AND T. W. QunN. 1998. Numts: a challenge for avian systematics and population biology. Auk 115:214-221.

SWOFFORD, D. S. 1998. Phylogenetic analysis using parsimony*, Version 4.0d64. Sinauer, Sunderland, MA.

TARr, C. L., AND R. C. Fleischer. 1993. Mitochondrial-DNA variation and evolutionary relationships in the amakihi complex. Auk 110:825-831.

VuILleUMIER, F. 1985. Forest birds of Patagonia: ecological geography, speciation, endemism, and faunal history. Ornithol. Monogr. 36:255-304.

WaLlace, A. R. 1852. On the monkeys of the Amazon. Proc. Zool. Soc. Lond. 20:107-110.

Walsh, S. P., D. A. Metzger, and R. Higuchi. 1991. Chelex 100 as a medium for simple extraction of DNA for PCR-based typing from forensic material. BioTechniques 10:506-513.

ZINK, R. M., AND R. C. BLACKWELl. 1998. Molecular systematics of the Scaled Quail complex (genus Callipepla). Auk 115:394-403.

The Condor 101:446-45!

(9) The Cooper Ornithological Society 1999

\title{
PHYLOGENETIC PATTERNS IN MONTANE TROGLODYTES WRENS'
}

\author{
Nathan H. Rice, A. Townsend Peterson and Griselda Escalona-Segura \\ Natural History Museum and Department of Ecology \& Evolutionary Biology, The University of Kansas, \\ Lawrence, KS 66045, email: nrice@falcon.cc.ukans.edu
}

Abstract. Phylogenetic studies based on mitochondrial DNA sequences of 10 species of wrens in Troglodytes and related genera suggest a new hypothesis of relationships for the group. The Winter Wren $(T$. troglodytes) and the anomalous Timberline Wren (Thryorchilus browni) are distantly related to the remainder of Troglodytes. The latter group divides into a tropical montane group and a northern/lowland group that includes the northernmost two montane taxa (T, rufociliatus, T. brunneicollis). Erection of the genus Nannus for the Winter Wren is proposed. Song evolution in the complex has involved either convergent derivation or retention of primitive song types in distant lineages.

Key words: mtDNA sequences, Nannus, phyloge$n y$, Troglodytes, wrens.

North American ornithologists are well-acquainted with the relatively simple song of the House Wren (Troglodytes aedon), in contrast to the long and complex song of the Winter Wren ( $T$. troglodytes). Recent field work in the mountains of southern Mexico and El Salvador brought two of us into contact with the Rufous-browed Wren ( $T$. rufociliatus); we were struck by the extreme similarity of its song with that of Winter Wrens. Further examination of Troglodytes song variation, in which two major song types were noted \footnotetext{
1998.
}

(Fig. 1), motivated the study reported herein. Songs of Northern and Southern House Wrens ( $T$. aedon and $T$. musculus, respectively) and Brown-throated Wrens ( $T$. brunneicollis) have long trills, whereas Winter, $\mathrm{Ru}$ fous-browed, Ochraceus ( $T$. ochraceus), and Mountain (T. solstitialis) Wrens all have longer, more varied songs largely lacking trills.

Our working hypothesis was that Winter Wrens might share a close phylogenetic relationship with the montane tropical forms of Troglodytes, representing an early lineage separate from the lowland forms. The only previous phylogenetic study of the genus did not include taxa critical to testing this hypothesis (Brumfield and Capparella 1996). Furthermore, morphometric studies of the entire genus by one of us (EscalonaSegura 1995) did not lead to firm conclusions regarding the evolutionary history of Troglodytes. For these reasons, we undertook a test of our hypothesis based on studies of mitochondrial DNA sequences.

\section{METHODS}

Tissue samples are listed in Table 1. One or two representatives of each mainland taxon that has at some point been considered as a species were included for analysis, as well as the enigmatic Timberline Wren (Thryorchilus browni, at times placed in Troglodytes) and outgroup taxa (White-breasted Wood-Wren Henicorhina leucosticta, Pinyon Jay Gymnorhinus cyanocephalus). Use of single or few individuals to represent taxa in phylogenetic analyses based on mitochondrial DNA sequence data follows Moore and DeFilippis 

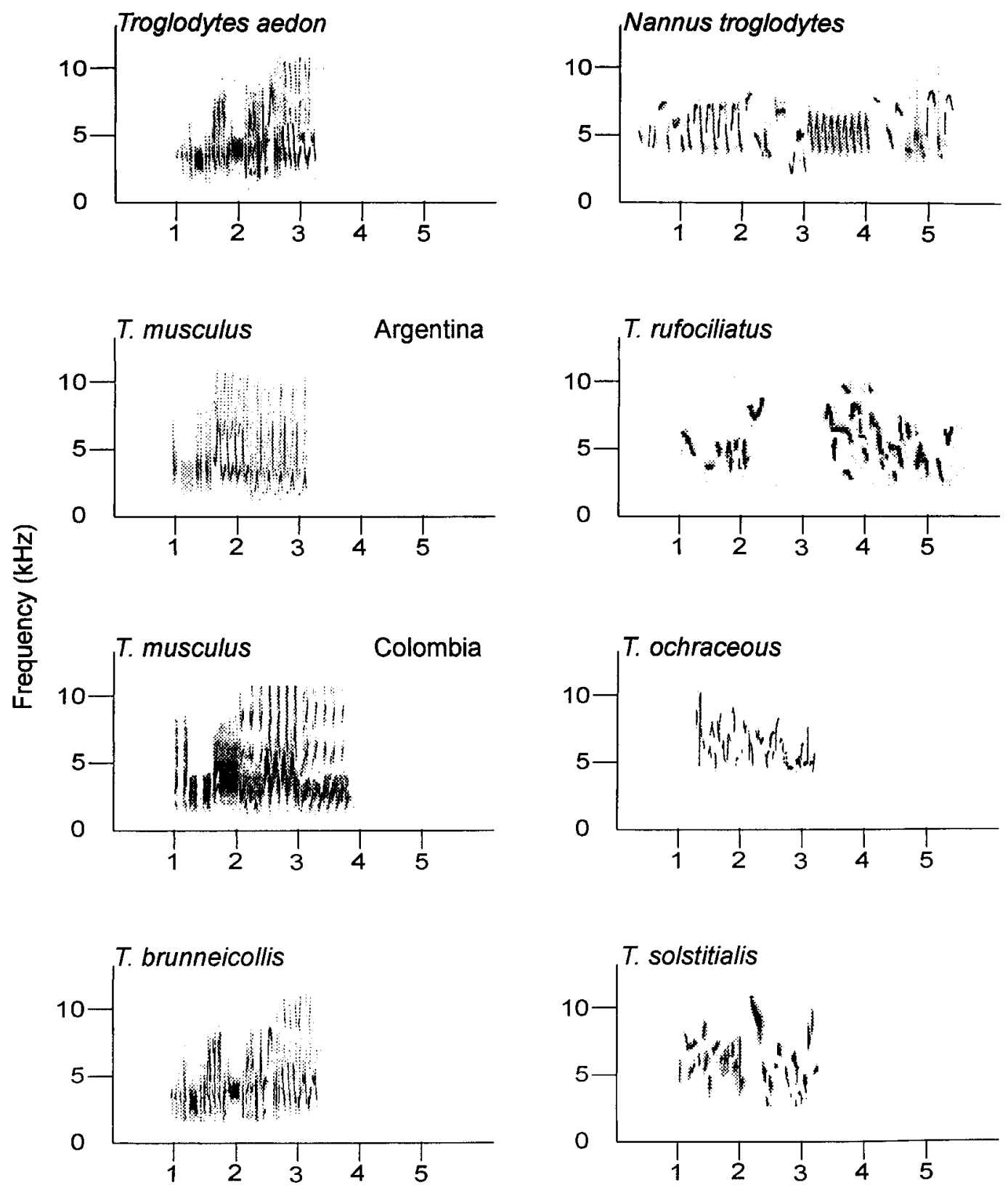

\section{Time (sec)}

FIGURE 1. Sonograms for representative Troglodytes and Nannus wren taxa examined in this study.

(1997), based on low levels of within-taxon sequence variation.

Genomic DNA was extracted from each sample using Qiamp tissue extraction kits available from Qiagen (Valencia, California). A 534 base pair (bp) portion of the ND2 gene was chosen for study, given the excel- lent resolution provided by this gene for species- and generic-level questions in other applications (Rice, unpubl. data). This segment was amplified using conventional thermal-cycling techniques, with a thermal profile of denaturing at $95^{\circ} \mathrm{C}$ for $30 \mathrm{sec}$, annealing at $55^{\circ} \mathrm{C}$ for $30 \mathrm{sec}$, and extension at $70^{\circ} \mathrm{C}$ for $90 \mathrm{sec}$ (Kocher 
TABLE 1. Tissue samples used in this study.

\begin{tabular}{|c|c|c|c|c|c|}
\hline \multicolumn{2}{|c|}{ Species } & Locality & \multirow{2}{*}{$\frac{\text { Collection }^{\mathrm{a}}}{\text { FMNH }}$} & \multirow{2}{*}{$\begin{array}{l}\text { Tissue number } \\
1785\end{array}$} & \multirow{2}{*}{$\begin{array}{c}\begin{array}{c}\text { GenBank } \\
\text { accession number }\end{array} \\
\text { AF } 104975\end{array}$} \\
\hline Winter Wren & Troglodytes troglodytes & Illinois & & & \\
\hline & & Illinois & FMNH & 1778 & AF 104976 \\
\hline \multirow[t]{2}{*}{ Northern House Wren } & T. aedon & Illinois & FMNH & 1815 & AF104979 \\
\hline & & Illinois & FMNH & 1783 & AF104980 \\
\hline Southern House Wren & T. musculus & Oaxaca, Mexico & MZFC & uncat. & AF104978 \\
\hline Brown-throated Wren & T. brunneicollis & Oaxaca, Mexico & $\mathrm{MZFC}$ & OMVP213 & AF104973 \\
\hline Rufous-browed Wren & T. rufociliatus & Chiapas, Mexico & $\mathrm{MZFC}$ & BMM607 & AF 104977 \\
\hline Ochraceous Wren & T. ochraceus & Cartago, Costa Rica & LSU & 19926 & AF104982 \\
\hline Mountain Wren & T. solstitialis & Pasco, Peru & LSU & 8178 & AF104981 \\
\hline Tepui Wren & T. rufulus & $\begin{array}{l}\text { Amazonas, } \\
\text { Venezucla }\end{array}$ & $\mathrm{LSU}$ & 7395 & AF 104983 \\
\hline Timberline Wren & Thryorchilus browni & Cartago, Costa Rica & LSU & 19924 & AF104974 \\
\hline \multicolumn{6}{|l|}{ White-breasted } \\
\hline Woodwren & Henicorhina leucosticta & Loreto, Peru & KU & 814 & AF104972 \\
\hline Pinyon Jay & $\begin{array}{l}\text { Gymnorhinus } \\
\text { cyanocephalus }\end{array}$ & $\begin{array}{l}\text { Baja California, } \\
\text { Mexico }\end{array}$ & FMNH & 1667 & AF 104971 \\
\hline
\end{tabular}

${ }^{\text {a }}$ FMNH $=$ Field Museum of Natural History, MZFC = Museo de Zoología of Universidad Nacional Autónoma de México, LSU = Louisiana State University Museum of Natural Science, KU = University of Kansas Natural History Museum.

et al. 1989). Extension time was lengthened 4 sec each cycle for 35 cycles. ND2 primers (H-6313: $5^{\prime}-$ CTCTTATTTAAGGCTTTGAAGGC-3' and L-5757: 5'-GGCTGAATRGGMCTNAAYCARAC-3') were developed by $\mathrm{M}$. Sorenson (pers. comm.; $\mathrm{H}$ and $\mathrm{L}$ refer to heavy and light strands, respectively, and numbers indicate relative position of primers on reference chicken sequence, Desjardins and Morais 1990). Amplified product was purified on a low-melt $(1 \%)$ NuSieve GTG agarose gel (FMC BioProducts; Rockland, Maine) electrophoresed for $45 \mathrm{~min}$ at $85-95$ volts; bands containing target products were excised from the gel, and DNA recovered using Qiaquick spin columns (Qiagen). Finally, purified product was amplified using one primer (heavy or light), and sequenced with an ABI Prism Automated Sequencer (Model 310). The thermal profile for both primer systems was denaturing at $96^{\circ} \mathrm{C}$ for $10 \mathrm{sec}$, annealing at $50^{\circ} \mathrm{C}$ for $5 \mathrm{sec}$, and extension at $60^{\circ} \mathrm{C}$ for $4 \mathrm{~min}$, re-

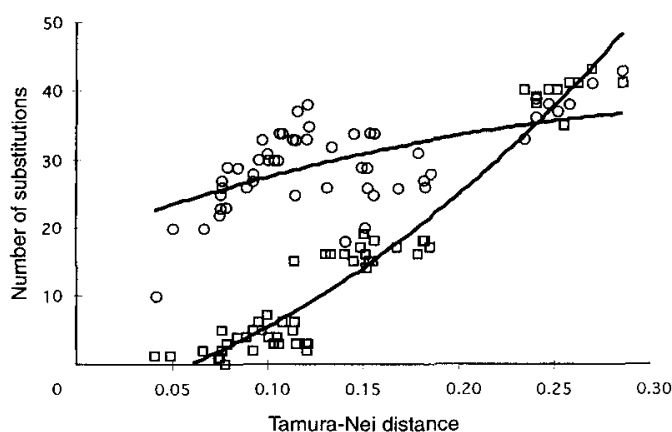

FIGURE 2. Third-position saturation curves for ND2 sequences, showing second-order polynomial fitted curves. Transitions are depicted with open circles, and transversions with open squares. peated for 25 cycles. Negative controls were used at each step to test for reagent contamination.

Numbers of variable and phylogenetically informative molecular characters, as well as numbers and classes of transitions and transversions, were calculated using MEGA 1.01 (Kumar et al. 1993). Rather than using percent sequence divergence as a distance measure to assess saturation, we used the Tamura-Nei Distance, which considers percent base composition for each individual, and is thus more robust than sequence divergence measures (Kumar et al. 1993). All sequences were deposited in GenBank (Table 1).

Phylogenetic trees were estimated based on sequence data using the exhaustive search procedure of PAUP (version 3.1.1, Swofford 1991), an approach guaranteed to identify shortest trees. Support for particular branches in resulting hypotheses was assessed using the branch-and-bound character bootstrapping algorithms in PAUP with 500 replicate searches, and counts of unreversed synapomorphies.

\section{RESULTS}

\section{BIOCHEMICAL PATTERNS}

Examination of sequences from the ND2 region revealed no insertions or deletions. Of the 534 base pairs examined, 215 were variable and 85 were phylogenetically informative. Partitioning bases by coding position revealed that 132 third position sites were variable, 60 of which were phylogenetically informative. At first and second positions, 61 (18 informative) and 22 (7 informative) sites, respectively, were variable.

Saturation of sequence substitutions was not detected either in the overall analysis or partitioning by coding position (Fig. 2). However, given the small size of the data matrix, we conducted exploratory analyses with different transition:transversion weighting schemes $(0: 1,1: 1,2: 1,5: 1$, and 10:1) and outgroup taxa (Henicorhina leucosticta and Gymnorhinus cyanocephalus). These tests suggested that the topology de- 


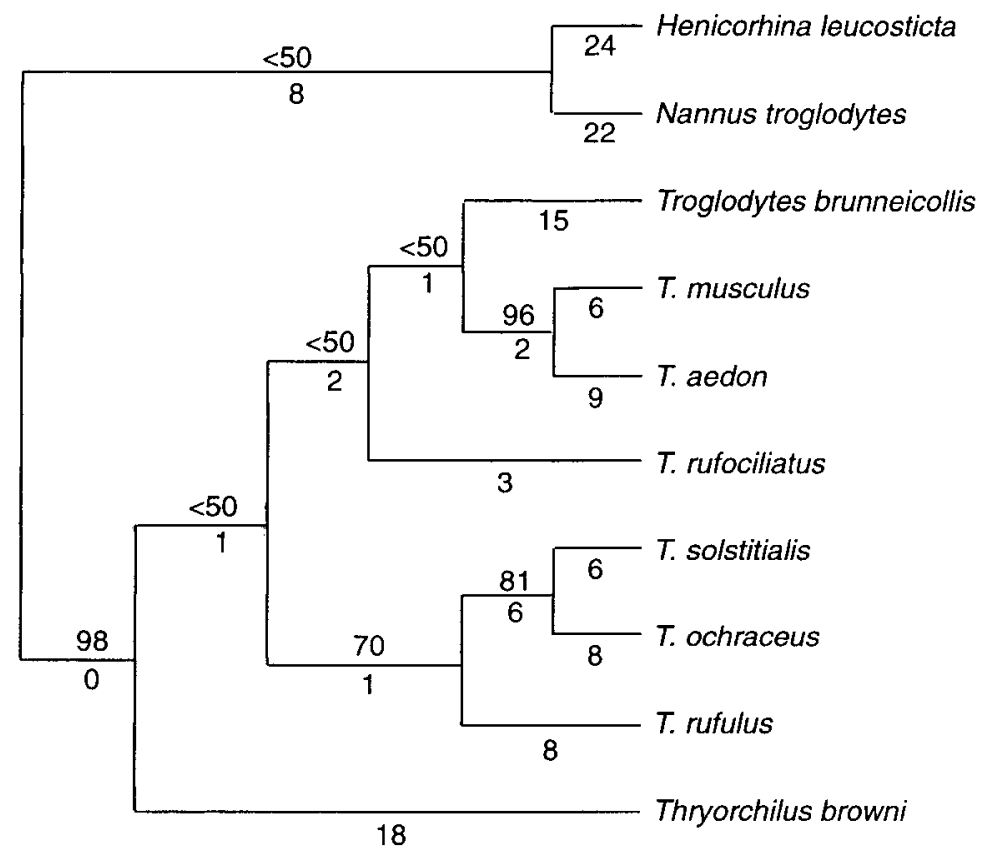

FIGURE 3. Cladogram showing the most parsimonious tree derived from analyses of sequences of the ND2 gene for montane Troglodytes wrens. Numbers above each node indicate bootstrap support, and those below each node are numbers of unreversed synapomorphies; those for terminal taxa represent numbers of autapomorphic base pairs.

veloped herein was robust to a variety of analytical techniques and warranted detailed examination. All members of the same species had identical sequences, so only one representative per taxon was used in subsequent analyses. Because choice of outgroup had little qualitative cffect on tree topologies, all further analyses were carried out with the White-breasted WoodWren as the sole outgroup.

\section{PHYLOGENETIC PATTERNS}

Exhaustive searches of the molecular data set rcsulted in a single most parsimonious tree of 256 steps; consistency index $(\mathrm{CI})=0.724$, homoplasy index $(\mathrm{HI})=$ 0.276 , retention index $(\mathrm{RI})=0.398$, rescaled consistency index $(\mathrm{RC})=0.288, \mathrm{~g}_{1}=-0.881$ (Fig. 3). The skew of the tree length histogram suggests that the shortest tree indeed contains significant phylogenetic signal $(P<0.01$; Hillis and Huelsenbeck 1992). Hence, we continued interpreting and exploring its implications.

The shortest tree did not support the monophyly of the genus Troglodytes. Rather, the Timberline Wren was placed as sister to most Troglodytes, and weak support existed for a sister relationship of Whitebreasted Wood-Wren and Winter Wren. The genus Troglodytes minus Winter Wren was supported as a monophyletic lineage by one unreversed synapomorphy.

Within the main Troglodytes lineage, two major clades were supported, one consisting of what has previously been called the House Wren complex (North- ern and Southern House Wrens, Brown-throated Wren) plus Rufous-browed Wren (supported by two unreversed synapomorphies), and the other clade including the Mountain, Ochraceous, and Tepui Wrens (T. rufulus; Fig. 3). Within the House Wren complex, Northern and Southern House Wrens were well-supported as sister taxa, with Brown-throated Wren forming the sister lineage. Unexpectedly, but supported by two unreversed synapomorphies, Rufous-browed Wren also was placed with the House Wrens, although this species has long been placed with, or even considered conspecific with, Mountain Wrens of Central and South America (Paynter 1957). Within the other major lineage, Mountain and Ochraceous Wrens were sister taxa, with Tepui Wren as sister species. This result suggests that the two lowland House Wrens were derived from within the 'montane wren' lineage.

\section{DISCUSSION}

The historical hypothesis developed herein is based on a single-gene lineage, and thus must be interpreted with some caution. Although support for nodes was not always strong, at least one unreversed synapomorphy was present for all nodes except one, suggesting that the hypothesis was supported by available data. Implications of this hypothesis for understanding the taxonomy and evolutionary patterns in songs of the group are discussed below.

Our results differ from those of Brumfield and Capparella (1996) regarding the relationships of the Northern and Southern House Wrens and the Brown-throat- 
ed Wren. Brumfield and Capparella (1996), using isozyme data, concluded that the Northern House Wren and Brown-throated Wren are sister taxa, and that the Southern House Wren is their sister taxon. Based on ND2 sequences, we found that the Northern and Southern House Wrens are sister taxa, with the Brownthroated Wren as sister. The conflict between the two hypotheses is illuminated by forcing the Brumfield and Capparella (1996) hypothesis onto our data set, which increased tree length by nine steps. Brumfield and Capparella (1996) did have more individuals per species sampled and better geographic representation of species. However, the allozyme results can be confusing, given the distant nature of the outgroup used (Winter Wren), the polymorphic nature of the characters used, and the small number of taxa represented. Hence, we suspect that the hypothesis presented herein will turn out to be better supported than that of Brumfield and Capparella (1996), but such a result must await further study of additional character suites.

\section{TAXONOMIC IMPLICATIONS}

Our tree suggests several points on which wren taxonomy needs revision. Some previous researchers placed the Timberline Wren within Troglodytes (e.g., Paynter and Vaurie 1960). Because of its placement basal to Troglodytes and its highly autapomorphic nature ( 18 unique bases; Fig. 3), it is unlikely to represent the sister taxon to Troglodytes. The diversity of outgroup taxa in the present study was insufficient to address this issue. Further investigations of wren systematics by colleagues (F. K. Barker, unpubl. data) will clarify this question.

The taxonomic affinities of the Rufous-browed Wren have long been unclear. Ridgway (1904) considered it as a member of the House Wren group. Hellmayr (1934), having not seen specimens, placed it as transitional between the Brown-throated Wren and montane forms to the south, and hypothesized that the group formed a single species. Others have considered it as separate from the House Wren group, placing it with Ochraceous and Mountain Wrens (Oberholscr 1904, Chapman and Griscom 1924, Paynter 1957). Our molecular results placed it close to the House Wrens; although bootstrap support for this hypothesis was not high, two unreversed synapomorphics were present. This result indicates that the Rufous-browed Wren is a latitudinal replacement of the Brown-throated Wren (Griscom 1932, Hellmayr 1934, Phillips 1986); its status as a species, however, given marked differences in song and plumage, is not in doubt.

Finally, our results suggest that Troglodytes, as currently defined, is polyphyletic. Exhaustive searches under varied assumptions all indicated that the Winter Wren is not part of the clade including other Troglodytes wrens examined in this study, which is somewhat surprising given our initial hypothesis that the Winter Wren and Rufous-browed Wren would be sister taxa! This revised vicw of the phylogenetic placement of Winter Wrens argues for its placement in a separate genus. Because the type species of Troglodytes is $T$. aedon (Paynter and Vaurie 1960), the remainder of the species presently placed therein should remain Troglodytes. An available genus for the Winter Wren is
Nannus (after Billberg 1848 in Paynter and Vaurie 1960), so we suggest its use for Winter Wrens. We suggest that the remainder of the species analyzed hercin (aedon, musculus, brunneicollis, rufociliatus, ochraceus, solstitialis, and rufulus), and by inference the insular "House Wrens" T. tanneri, T. beani, and "Thryomanes" sissonit, be retained as members of the genus Troglodytes.

\section{SONG EVOLUTION}

The hypothesis that motivated this study-that Winter Wrens form a sister lineage to the montane tropical Troglodytes wrens-was clearly falsified by the molecular data. This result suggests that song evolution in the group has been complex, and that song characters should be used with caution when formulating or supporting systematic hypotheses. Nowhere is this morc obvious than in "House" wrens, in which insular forms have derived songs strikingly different from those of mainland populations. Surprisingly similar songs either evolved independently in Winter Wrens and the montane tropical Troglodytes, or are the primitive song type for a broad lineage of wrens.

Troglodytes (excluding Nannus) divides clcarly into two lineages. One includes the southern montane tropical forms, all of which have the complex "Winter Wren" song. The other has Rufous-browed Wren placed basally ("Winter Wren" song) to the lowland forms plus Brown-throated Wren (trilled song). This arrangement suggests that the trilled song was derived from the "Winter Wren" song, forming a synapomorphy defining the House Wren + Brown-throated Wren lineage.

\section{LOWLAND VS. MONTANE HABITATS}

The Troglodytes assemblage represents two broadly distributed complexes of lowland (aedon and musculus) and montane (brunneicollis, rufociliatus, ochraceus, solstitialis, rufulus) habitats in close apposition altitudinally throughout much of the Americas. An interesting question is the pattern of invasion of lowlands or highlands - (1) a montane clade nested within lowland forms would indicate lowland origin and a single invasion of highlands, (2) a lowland clade nested within highland forms would indicate highland origin and a single invasion of the lowlands, and (3) a series of sister relationships of lowland and montane forms would indicate independent invasions of different latitudinal bands. The results of our study strongly supported the second hypothesis. The two lowland forms (sister taxa) were nested within four hicrarchical levels of montane taxa, suggesting that the pattern of invasion was into the lowlands from the highlands.

Walter W. Dimmick and Edward O. Wiley provided laboratory support and equipment for this study. Tissue samples were kindly made available to us by the Louisiana State University Muscum of Natural Science, Musco de Zoología of the Universidad Nacional Autónoma México, and the Field Museum of Natural History (Chicago, Illinois). Song recordings were provided by the Cornell Library of Natural Sounds and Bret Whitney. F. Keith Barker provided many helpful ideas, and Mark B. Robbins, Walter D. Koenig, David J. Gubernick, and two anonymous reviewers provided 
comments on earlier versions of this paper. This work was funded in part by a grant from the University of Kansas General Research Fund to ATP, by a scholarship from the Conéjo Nacional de Ciencia y Tecnología (scholarship 88964) to GES, and by a Frank M. Chapman Fund grant from the American Museum of Natural History to NHR.

\section{LITERATURE CITED}

Brumfield, R. T., and A. P. Capparella. 1996. Genetic differentiation and taxonomy in the House Wren species group. Condor 98:547-556.

Chapman, F. M., AND L. Griscom. 1924. The House Wrens of the genus Troglodytes. Bull. Am. Mus. Nat. Hist. 50:279-304.

Desjardins, P., AND R. Morias. 1990. Sequence and gene organization of the chicken mitochondrial genome: a novel gene order in higher vertebrates. J. Mol. Biol. 212:599-634.

EsCALONA-SEgura, G. 1995. Variación geográfica de las formas Norte y Centroamericanas del género Troglodytes, con enfasis en $T$. brunneicollis, $T$. rufociliatus y $T$. ochraceus. M.Sc. thesis, Facultad de Ciencias, Universidad Nacional Autónoma de México, Mexico City, Mexico.

Griscom, L. 1932. The distribution of bird-life in Guatemala. Bull. Am. Mus. Nat. Hist. 64:1-439.

Hellmayr, C. E. 1934. Catalogue of birds of the Americas and the adjacent islands. Field Mus. Nat. Hist. Zool. Ser. 19:1-472.

Hillis, D. M., AND J. P. Huelsenbeck. 1992. Signal, noise, and reliability in molecular phylogenetic analyses. J. Heredity 83:189-195.
Kocher, T., W. Thomas, A. Meyer, S. Edwards, A. PÄÄBO, F. VillablanCA, AND A. WILsON. 1989. Dynamics of mitochondrial DNA evolution in animals: amplification and sequencing with conserved primers. Proc. Natl. Acad. Sci. 86:61966200 .

Kumar, S., K. Tamura, and M. NeI. 1993. MEGA: molecular evolutionary genetics analysis, version 1.01. Pennsylvania State Univ., Univ. Park, PA.

LANYON, W. E. 1960. Relationship of the House Wren (Troglodytes aedon) of North America and the Brown-throated Wren (Troglodytes brunneicollis) of Mexico. Proc. Int. Ornithol. Congr. 12:450458.

MoOre, W. S., ANd V. R. DeFilippis. 1997. The window of taxonomic resolution for phylogenies based on mitochondrial cytochrome $b$, p. 83-119. In D. P. Mindell [ed.], Avian molccular evolution and systematics. Academic Press, San Diego.

Orerholser, H. C. 1904. A review of the genus Troglodytes. Proc. US Nat. Mus. 27:197-211.

PAYNTER, R. A., JR. 1957. Taxonomic notes on the New World forms of Troglodytes. Breviora 71:115.

PAYNTER, R. A., JR., AND C. VAuRIE. 1960. Family Troglodytidae, p. 379-440. In E. Mayr and J. C. Greenway [eds.], Check-list of birds of the world. Vol. 9. Mus. Comp. Zool., Cambridge, MA.

Phillips, A. R. 1986. The known birds of North and Middle America. Part I. Denver Mus. Nat. Hist., Denver, $\mathrm{CO}$.

SwOFFORD, D. L. 1991. PAUP: phylogenetic analysis using parsimony. Version 3.1.1. Illinois Nat. Hist. Survey, Champaign, IL.

\title{
DISPERSAL AND POPULATION STRUCTURE IN THE EUROPEAN STARLING
}

\author{
Paul R. CABE ${ }^{2}$ \\ Department of Ecology, Evolution, and Behavior, University of Minnesota, St. Paul, MN 55108
}

\begin{abstract}
Dispersal in birds can be estimated in several ways, including the use of banding data and the indirect use of genetic data. This study uses both of these to estimate dispersal and genetic population structure in the European Starling (Sturnus vulgaris) in North America. Banding data imply that natal dispersal is quite high, and this finding is supported by the observed rapid colonization of North America. Genetic data, based on allozyme allele frequencies from
\end{abstract}

\footnotetext{
' Received 25 June 1998. Accepted 6 January 1999

${ }^{2}$ Current address: Biology Department, St. Olaf College, Northficld, MN 55057-1098, e-mail: cabe@stolaf.edu
}

populations in Virginia, Vermont, Colorado, and California, are consistent with a species with large demes and high rates of dispersal.

Key words: dispersal, European starling, population structure, Sturnus vulgaris.

Natal dispersal allows for the exchange of individuals among existing populations and provides individuals to colonize new arcas. Thus, this process is integrally associated with the genetic structure of populations. Unfortunately, it is often very difficult to make direct and accurate estimates of natal dispersal. Banding data have offered important insights into both seasonal movements and dispersal. An alternative is the use of 